\title{
Abalone, Haliotis mariae (Wood, 1828), Hatchery and Seed Production Trials in Oman
}

\author{
Khalfan M. Al-Rashdi*1 and Tsueno Iwao \\ ${ }^{1}$ Ministry of Fisheries Wealth, Aquaculture Center, \\ P.O. Box 427, PC 100, Muscat, Sultanate of Oman \\ ${ }^{2}$ Japan International Cooperation Agency, Fisheries Department, Japan \\ تجارب تفريخ وإنتاج صغار الصفيلح في سلطنة عمان \\ خلفان م. الراشدي و ت. إواو
}

الخلاصة: أجريت تجارب تفريخ و انتاج صغار الصفيلح العماني بمحطة إنتاج صغار الصفيلح بو لاية مرباط خلال الفترة مابين 1999

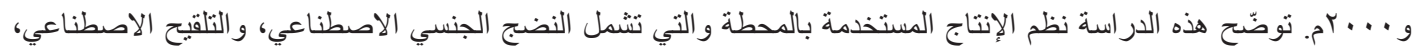

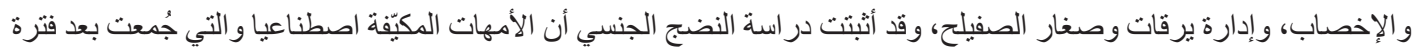

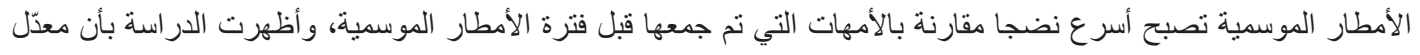

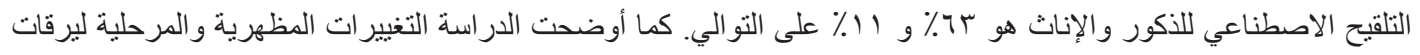

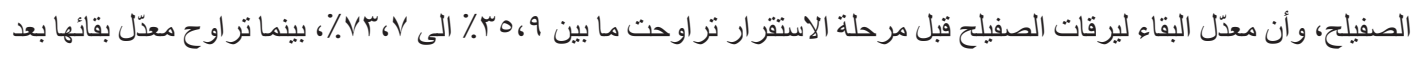

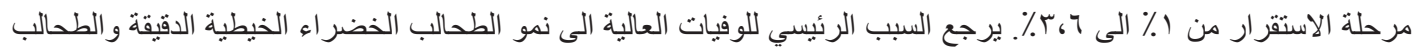

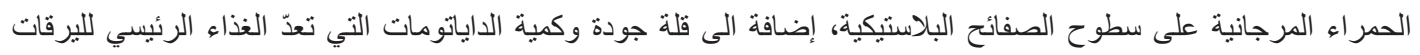

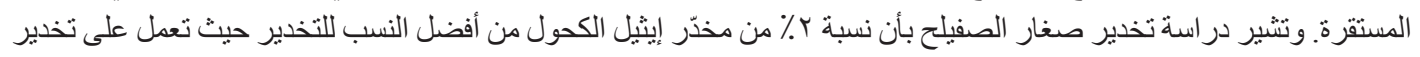

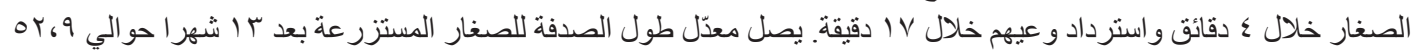

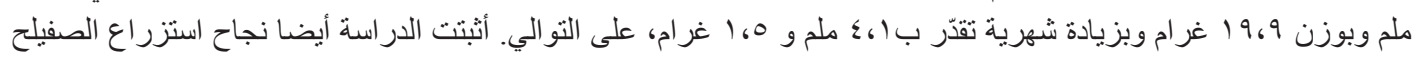
العماني وأن إقامة مز ارع تجارية أمر جير بأن يؤخذ في بادي الاعتبار.

ABSTRACT: Hatchery and seed production trials for the Omani endemic abalone Haliotis mariae were carried out at the land-based Mirbat Abalone Seed Production Station in Oman between 1999 and 2000. The methods developed for broodstock conditioning, induction of spawning and fertilization, larval settlement, and the handling of small juveniles are shown. Abalone collected in the post-monsoon period and held for 2 months matured faster than those collected before the monsoon and held for 6 months. Spawning induction of males and females had $63 \%$ and $11 \%$ success rates respectively, and the morphology of early larval stages is shown. Survival rates of veliger larvae introduced to settlement plates ranged from $35.9 \%$ to $73.7 \%$, but the survival of post-larvae was low at $0.1 \%$ to $3.6 \%$. The high mortality rate was attributed to invasions of filamentous greenand coralline algae on settlement plates and occurrence of low quantity of diatoms as food. Juveniles reacted best to $2 \%$ ethanol as anaesthetic, dropping off culture plates within $4 \mathrm{~min}$ and recovering within $17 \mathrm{~min}$. Cultured abalone reached an average shell length of $52.9 \mathrm{~mm}$ over 13 months, which translates to an increment of $4.1 \mathrm{~mm} . \mathrm{mon}^{-1}$. The overall conclusion of these preliminary research trials confirms that $H$. mariae can be cultured successfully in Oman. Further studies on the standardization of the techniques would help in stock enhancement programmes and commercial farming.

Keywords: Haliotis mariae, aquaculture, seed production, larval settlement, growth, Oman

\section{Introduction}

The abalone Haliotis mariae (locally called As'sufailah) is endemic to the subtropical Arabian Sea coast of southern Oman, where it inhabits inter- and subtidal rocky substrates down to $20 \mathrm{~m}$ depth (Bosch and Bosch, 1982; Johnson et al., 1992). In this habitat, abalone shelter among rocks and in crevices during daytime and forage nocturnally. Larger individuals

*Corresponding author. E-mail: Omanaba@yahoo.com / Krashdi@maf.gov.om 


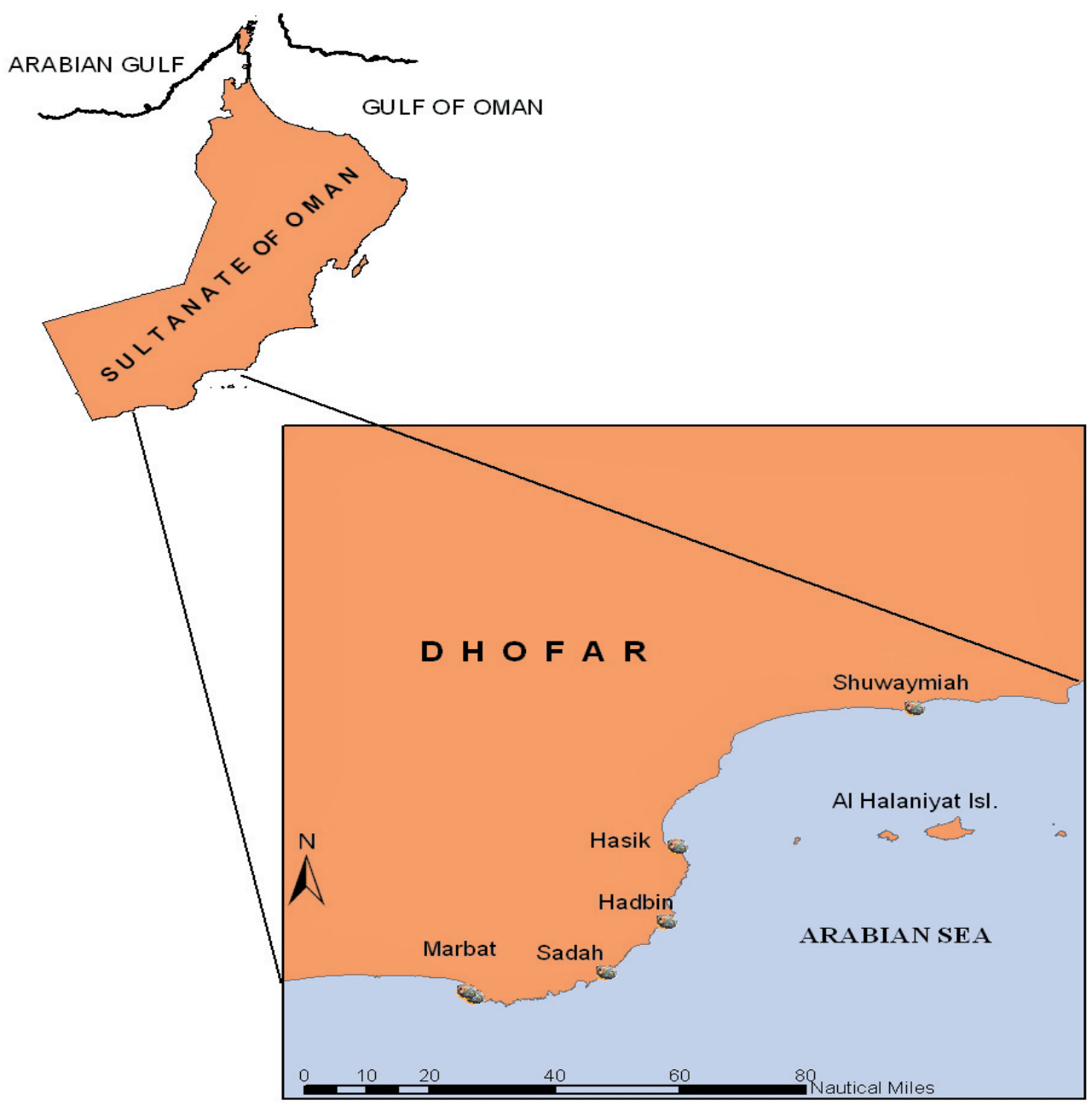

Figure 1. Map of Oman with important locations for abalone fisheries at Dhofar Region.

occur in deeper areas than smaller animals (Anon, 1984).

The life cycle of $H$. mariae is related to the southwest monsoon driven upwelling that occurs from June to August (Johnson et al., 1992), which decreases seawater temperature and increases nutrient concentrations (Barratt et al., 1986). During the premonsoon (March-May) and monsoon period, the brown and red algae on which $H$. mariae predominantly feed are scarce or absent (Barratt et al., 1984; Jupp, 2002). In the post-monsoon months of September to February, abalone move into shallower waters to reproduce and feed (Al-Hafidh, 2006). Females appear to spawn once a year with a peak spawning during December and
January, and a gradual decrease during February and March as algae become scarce (Al-Hafidh, 2006). Sea urchins appear to be a competitor for food (Tripneutes gratilla) and living space (Diadema spp.), and natural predators on abalone include scalloped spiny lobster (Panulirus homarus), seastars (Asterias spp.), octopus (Octopus aegina), cuttlefish (Sepia spp.) and finfishes like morays (Gymnothorax spp.).

A fishery for H. mariae is concentrated around Sadah, with catches declining towards Sharbithat in the East and Mirbat to the West (Fig. 1). The annual production of abalone from a two-month fishing season (Table 1) was estimated at $50 \mathrm{t}$ in 2006, valued at more than US\$ 8 million (MAF, 2007). 
Table 1. Total catch (tons) and value (Oman Rial) data in the Arabian abalone fishery, 1997-2006. (MAF, 2007).

\begin{tabular}{lcc}
\hline Year & Catch (t) & Value (O.R) \\
\hline 1997 & 40 & 2384330 \\
1998 & 32 & 1703784 \\
1999 & 29 & 1434116 \\
2000 & 44 & 2249273 \\
2001 & 51 & 2477000 \\
2002 & 50 & 2597000 \\
2003 & 56 & 3101000 \\
2004 & 57 & 3146000 \\
2005 & 49 & 2649000 \\
2006 & 50 & 3171000 \\
\hline
\end{tabular}

Economically, it has the highest yield per $\mathrm{kg}$ of all Omani fisheries products. Intense fishing by locals using free diving methods have led to sharp decline in catches, and abalone stock is presently regarded as overfished (Al-Hafidh, 2006).

The aquaculture of abalone on a commercial scale has developed rapidly in several countries including the USA, Mexico, South Africa, Australia, New Zealand, Japan, China, Taiwan, Ireland and Iceland (Hahn, 1989; Gordon and Cook, 2001). Specific culture techniques need to be developed or adapted for each abalone species. The geography and subtropical climate of Oman with warm clean coastal waters lends itself to aquaculture, and $H$. mariae furthermore has a unique yellow foot and excellent meat texture. Given the high value of abalone products on international markets and the decline of wild stocks, the aquaculture of $H$. mariae in Oman was investigated in a series of projects since 1994, the resources of which are available in several internal- and unpublished reports (Ogawa, 1994, 1997; Iwao, 2000; Al-Rashdi, 2001; Endo, 2005), but have not appeared in the peerreviewed literature. This paper reviews the progress of the abalone aquaculture trials in Oman, with emphasis on the development of the culture facilities, hatchery and handling techniques, and constrains to the culture of $H$. mariae.

\section{Materials and Methods}

\section{Study site and culture system}

Mirbat bay was selected as the site for the Mirbat Abalone Seed Production Station (MASPS) based on several criteria. The bay is characterized as semi- closed, opens to the Arabian Sea in an eastward direction, and is only moderately affected by wind and adverse sea conditions during the monsoon season. It has clean and unpolluted coastal waters. Several seaweed species are available in the vicinity as abalone food, and Mirbat town is close to markets and other existing infrastructure.

A Land-Based (L-B) culture system with seawater pumped and filtered on a $24 \mathrm{~h}$ basis from $270 \mathrm{~m}$ offshore at a maximum capacity of about $120 \mathrm{t} . \mathrm{h}^{-1}$ (only $20 \mathrm{t}^{\mathrm{h}} \mathrm{h}^{-1}$ utilized) was installed. Water was filtered to $40 \mu \mathrm{m}$ to prevent invasion of fouling organisms.

\section{Broodstock collection and conditioning}

H. mariae broodstock of 60-120 mm shell length (SL) were collected from the wild in May (pre-monsoon) and September (post-monsoon) by SCUBA diving during the daytime at depths of 5-20 m. Care was taken not to damage the foot while dislodging them from the substratum. Animals were transported to the hatchery within $4 \mathrm{~h}$ using a cool box containing a wet sponge to absorb excretory products and ice to reduce temperature and metabolic rates. The total SL and weight of each abalone were measured using a vernier caliper $( \pm 0.1 \mathrm{~mm})$ and electronic balance $( \pm 0.1 \mathrm{~g})$.

Artificial conditioning trials were carried out in 10001 capacity rectangular fiberglass tanks over 4month and 6-month periods, respectively for abalone collected before and after the monsoon period. Densities in tanks were limited to 25-60 individuals per tank. Inverted V-shaped Glass Reinforced Plastic (GRP) structures were placed at the bottom of the tanks as shelters. The water was filtered through three layers of sand and then recycled at an ambient temperature of $26-28^{\circ} \mathrm{C}$. The water was re-circulated and re-filtered to allow microorganisms to eliminate ammonia, and aeration was provided. An artificial photoperiod (12L:12D) was maintained with a light intensity of approximately 150 lux at the bottom of the tank during the daylight hours. Broodstock were fed daily with green alga, Ulva fasciata, at a rate of $10 \%$ of the total body weight. A gonad maturity stage was defined by visual assessment as follows: stage (0) - no gonadal development visible: stage (1) - immature, with the level of the shell edge higher than the gonad coverage: stage (2) - mature, with the level of the shell edge equal to the level of the gonad coverage: and stage (3) - fully mature, with the shell edge lower than the gonad coverage (Fig. 2). The collected broodstock had mostly immature gonads (stage 1) at the onset of conditioning. A maturity index was calculated as the average of individual gonad maturity stages in each month. 


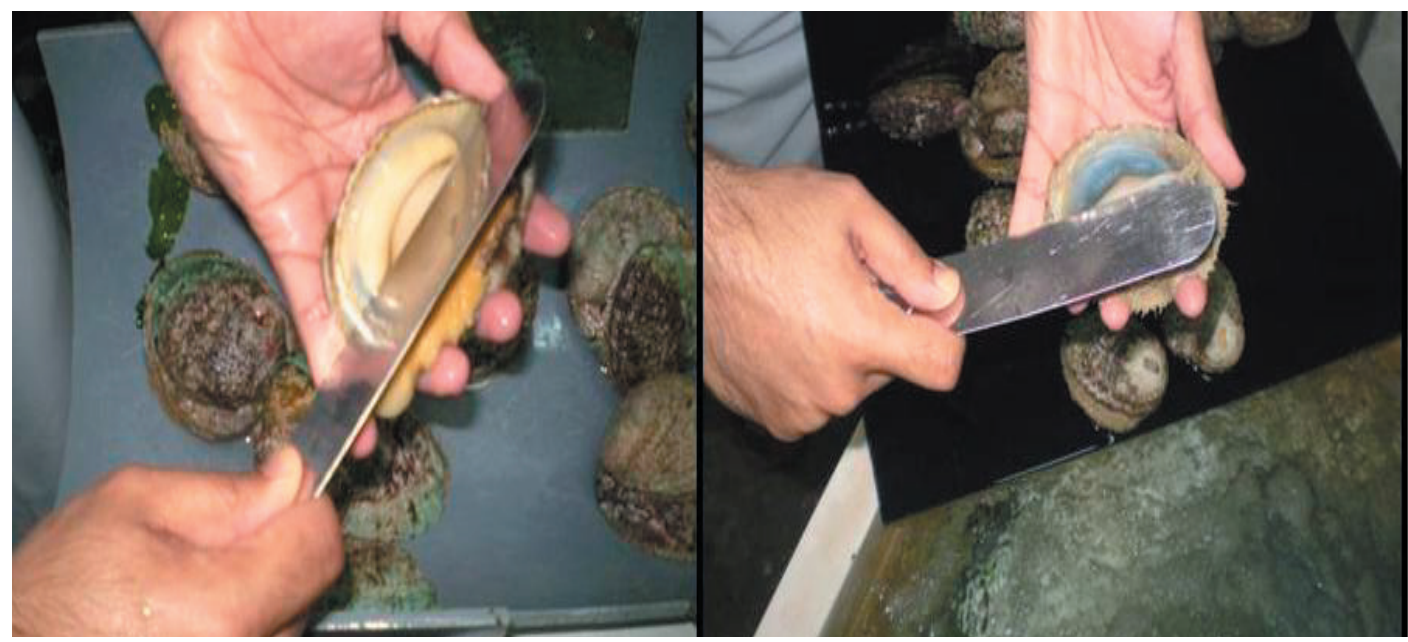

Figure 2. Fully-mature abalone. A male having a milky white testis, while a female having a dark green ovary.

\section{Spawning induction and fertilization}

Spawning was induced following the method developed by Kikuchi and Uki (1975) for H. discus hannai in Japan. Broodstock were first exposed to the air for an hour and then immersed in filtered irradiated sea water with ultraviolet (UV) light at slightly elevated temperature $\left(+3^{\circ} \mathrm{C}\right)$. The UV irradiation dose level used was 2400 m.W.h. $1^{-1}$ at flow rates of 200 ml.min ${ }^{-1}$, distributed equally to ten 201 aquaria. The broodstock were then left undisturbed and checked for spawning every hour for the first $3 \mathrm{~h}$ and then for every $30 \mathrm{~min}$ for a further $5 \mathrm{~h}$.

After spawning, eggs were siphoned out of the aquaria and filtered through a $300 \mu$ mesh to remove unwanted particles, and the number of eggs was counted under binocular microscope by taking $5 \mathrm{ml}$ sub-samples from egg water aquaria. Fertilization was carried out according to Hahn's (1989) technique. Eggs were maintained at the bottom of 201 aquarium in a single layer (approximately 400,000 eggs in 21 of water) and then fertilized with a mixture of sperms $(100,000$ sperm per ml) collected from several spawning males. The eggs and sperms were left for 15 min for fertilization. After all the fertilized eggs settled at the bottom, the upper water layer was decanted off and the fertilized eggs aquarium was refilled with filtered irradiated sea water. This washing process was repeated 10 times at intervals of $20 \mathrm{~min}$ (Hahn, 1989). The fertilization rates were estimated by aliquot sampling (Ebert and Houk, 1984). Aquaria were kept in the dark in an air-conditioned room until hatching.

\section{Larval rearing}

The newly hatched trochophore larvae swim to the surface, leaving the egg debris and aberrant larvae at the bottom. The healthy trochophores were decanted immediately into separate sterilized aquaria to avoid bacterial contamination (Hahn, 1989). The water level in the aquaria was made up to 151 with filtered sterilized seawater. The rearing was undertaken until the larval shell was completely formed.

\section{Primary film formation and larval settlement}

Settlement and metamorphosis of $H$. mariae larvae were carried out on $0.33 \mathrm{~m} \times 0.33 \mathrm{~m}$ polycarbonate transparent flat culture plates set as artificial substrates. The plates were first prepared by exposing them to a continuous through flow of sand-filtered seawater in outdoor tanks for less than 60 days. This process covers the plate surfaces with a primary film of organic material with a complex microbial community, mainly diatoms (Hahn, 1989).

Five sets of 60 plates each were suspended vertically in two indoor rectangular fiberglass tanks $(2.2 \mathrm{~m} \times 1.2 \mathrm{~m} \times 0.5 \mathrm{~m})$ filled with filtered UV sterilized seawater, and the water level was adjusted to cover all plate surfaces. The metamorphic larvae were stocked at a density of 300 to 480 larvae per plate after which the water circulation was initiated at 300 


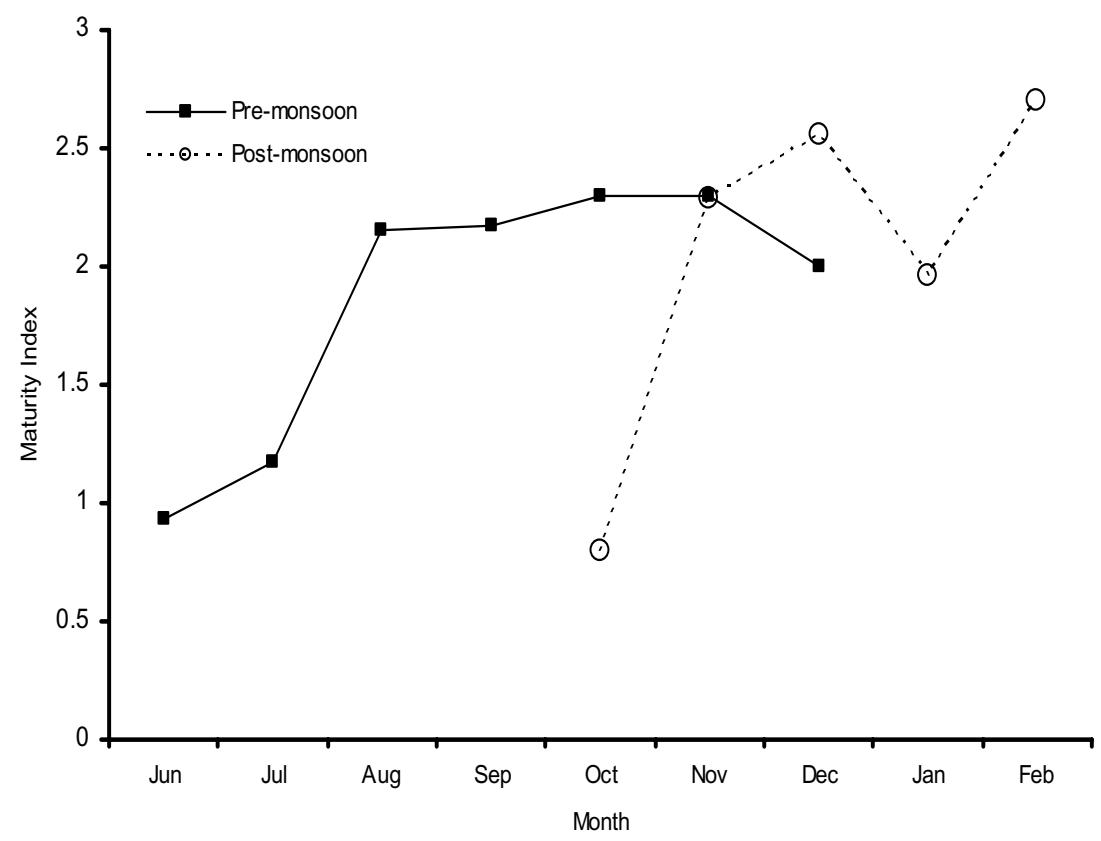

Figure 3. Changes in the maturity index of $H$. mariae from the pre-monsoon (May) and post-monsoon (September) samples, and conditions for six months and two months, respectively, prior to spawning.

$1 . h^{-1}$ through a perforated pipe along the tank bottom, and the water was aerated. Changes in larval external morphology were studied by regularly cutting off small pieces of plates from 3 sets and examining the developing larvae under the microscope. After 7-15 days the settlement plates were transferred to outdoor circular tanks for further rearing. Total survival was determined after one month by counting surviving juveniles.

\section{Handling of juveniles and grow-out}

To detach thin-shelled juveniles for transfer between tanks or other purposes (Hahn, 1989), 70\% ethanol was diluted to concentrations of $1 \%, 2 \%$ and $4 \%$, and the drop-off and recovery times of 10 juveniles (10-20 mm in size) were measured in each dilution. ANOVA was used to compare the drop-off and recovery times between the three treatments (Zar, 1996). Juveniles produced at MASPS were maintained for 13 months at ambient temperature to assess growth rates.

\section{Results and Discussion}

The culture of abalone is a high priority project in Oman, owing to the high value product and demand on international markets. Wild stocks are overfished and food-limited during the monsoon season, and faster growth rates than in nature may be achievable through culture (Johnson et al., 1992; Shepherd et al., 1995).

The maturity index of the broodstock collected in the pre-monsoon (May) increased between June and August, and all the individuals had mature gonads by the end of the period in December over a period of 6 months (Fig. 3). The maturity index of breeders in the post-monsoon (September) samples increased over a shorter period and reached higher value in December over 60 days (Fig. 3). After the spawning inducement in December, the samples were returned into conditioning tank and regained full maturity in February, over another 60 days (Fig. 3). The postmonsoon group was collected from the wild at the onset of the reproductive season, and was presumably physiologically ready for maturation. Regardless of 
Table 2. Conditioning period of various abalone species.

\begin{tabular}{|c|c|c|}
\hline $\begin{array}{l}\text { Abalone } \\
\text { species }\end{array}$ & $\begin{array}{l}\text { Conditioning } \\
\text { period (days) }\end{array}$ & Source \\
\hline Haliotis mariae & 60 & This study \\
\hline $\begin{array}{l}\text { Haliotis discuss } \\
\text { hannai }\end{array}$ & 80 & $\begin{array}{l}\text { (Uki and } \\
\text { Kikuchi, } \\
\text { 1984) }\end{array}$ \\
\hline $\begin{array}{l}\text { Haliotis } \\
\text { rufescens }\end{array}$ & 90 & (Ault, 1985) \\
\hline Haliotis discus & 160 & $\begin{array}{l}\text { (Kafuku and } \\
\text { Ikenoue, } \\
\text { 1983) }\end{array}$ \\
\hline $\begin{array}{l}\text { Haliotis } \\
\text { laevigata }\end{array}$ & $90-120$ & $\begin{array}{l}\text { (Grove-Jones, } \\
1996)\end{array}$ \\
\hline Haliotis roei & $>180$ & $\begin{array}{l}\text { (Freeman, } \\
\text { 2001) }\end{array}$ \\
\hline
\end{tabular}

the controlled conditioning methods applied in various abalone species, the result of shorter conditioning period achieved in our experiment (60 days) was better than that obtained with several abalone species (Table 2 ). Therefore, it is advantageous to collect broodstock in September, because the shorter conditioning time required will reduce costs.

Four spawning inducement trials were carried out successfully between December 1999 and April 2000 (Table 3). Spawning occurred mainly during nighttime at a temperature of $25-27^{\circ} \mathrm{C}$. The pattern was similar to tropical abalone $H$. asinina in the Philippines (Capinpin and Hosoya, 1995; Fermin et al., 2000) and $H$. varia in India (Najmudeen and Victor, 2004). Spawning in males occurred $3 \mathrm{~h}$ after immersion in UV-irradiated seawater; whereas, in females it was after $5 \mathrm{~h}$. Males spawned more frequently than females, which facilitated higher fertilization rates. The success rates of male and female spawning induction averaged about $63 \%$ and $11 \%$ respectively (see Table 3). However, spawning success rate of 50\% or more was obtained with female $H$. ruber and $H$. laevigata, using UV irradiation and temperature shock methods (Grubert and Ritar, 2005; Daume, 2007). The low rate may have resulted from incorrect technique of UV stimulation (Hahn, 1989) or the female broodstock not being sufficiently ripe for these stimulus (Morse, 1984), thus technical modifications on female $H$. mariae spawning induction and further work on testing other spawning methods are required.

The total number of eggs spawned in the four trials ranged from $0.59-2.8$ million per female with a shell length of $60-80 \mathrm{~mm}$. Al-Rashdi (2001) suggested that larger female $H$. mariae (>110 mm SL) can spawn as much as 5 million eggs. This compares well with other species: 5.2 million eggs in H. gigantea (Yoo, 1989), 0.3 million in $H$. discus hannai (Yoo, 1989), 0.2 million in $H$. diversicolor supertexta (Chen, 1989) and 0.08 million in $H$. varia (Najmudeen and Victor, 2004). Fertilized eggs were spherical and $200 \mu \mathrm{m}$ in diameter (Fig. 4). The fertilization rates varied between $72 \%$ and $98.6 \%$ (see Table 3).

Hatching of $H$. mariae occurred $8 \mathrm{~h}$ and $25 \mathrm{~min}$ after fertilization at $23.6^{\circ} \mathrm{C}$ and $6 \mathrm{~h}$ and $30 \mathrm{~min}$ at $24.7^{\circ} \mathrm{C}$ (Ogawa, 1997), and the external morphology of larvae

Table 3. Data on the spawning success of Haliotis mariae broodstock from the various trials. The number in parenthesis indicate the number of broodstock tested for each spawning trial.

\begin{tabular}{|c|c|c|c|c|}
\hline Trial No. & 1 & 2 & 3 & 4 \\
\hline Date & 13.12 .99 & 16.12 .99 & 23.01 .00 & 01.04 .00 \\
\hline Water temperature $\left({ }^{\circ} \mathrm{C}\right)$ & $\begin{array}{c}26 \\
+2(15)\end{array}$ & $\begin{array}{c}25 \\
+1(17)\end{array}$ & $\begin{array}{c}26.5 \\
+22(15)\end{array}$ & $\begin{array}{c}27 \\
\text { } 2(17)\end{array}$ \\
\hline No. of spawners & ภิ $9(11)$ & ภิ $7(12)$ & $\delta 7(12)$ & $\delta 6(11)$ \\
\hline No. of eggs $\left(10^{4}\right)$ & 282 & 59 & 68.7 & 500 \\
\hline Fertilization rate $(\%)$ & 72.5 & 98.6 & 88.7 & 90.4 \\
\hline
\end{tabular}




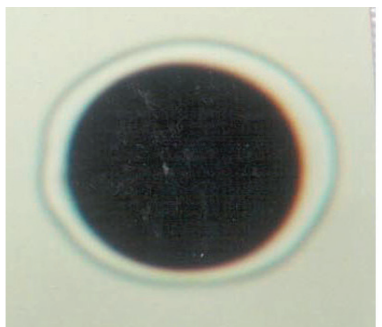

1

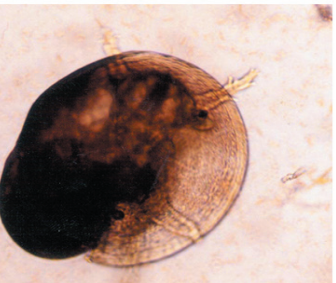

5

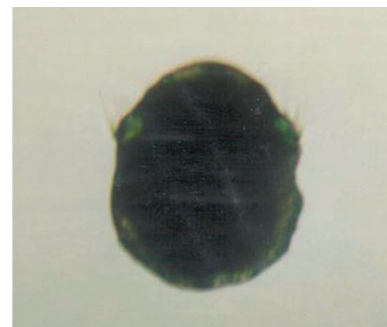

2

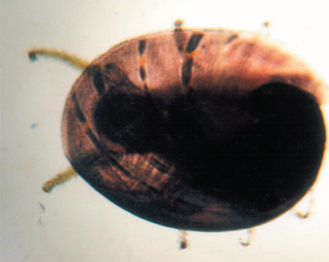

6

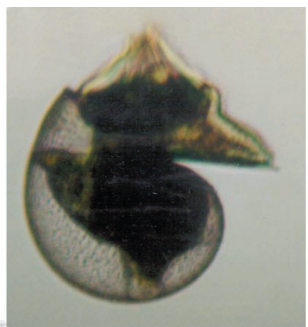

3

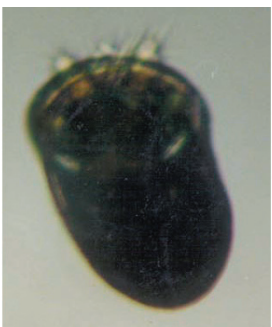

4

Figure 4. Embryonic development of $H$. mariae from eggs to seed production $\{1$ : fertilized egg $(200 \mu \mathrm{m}), 2$ : newly hatched out larva (trochophore, $210 \mu \mathrm{m}), 3$ : pre-settlement veliger larva, 4: metamorphosed larva, 5: newly settled larvae, 6: post-settlement larva with shell formation, 7: early juvenile with first respiratory pore in the shell (2.5mm, 30 days), and 8 : a produced seed in the hatchery (25mm, 120 days) .

over the next 30 days, from hatching to plantigrade veliger stage, is shown in Fig. 4. The laboratory observation of the $H$. mariae larval development indicated that there were no obvious differences between the external morphology of $H$. mariae larvae compared to H. discus hannai larvae (Seki and Kanno, 1977), except that $H$. mariae developed faster, presumably because of higher water temperatures (S.A. Shepherd, personal communication). The survival rates from trochophore to plantigrade veliger

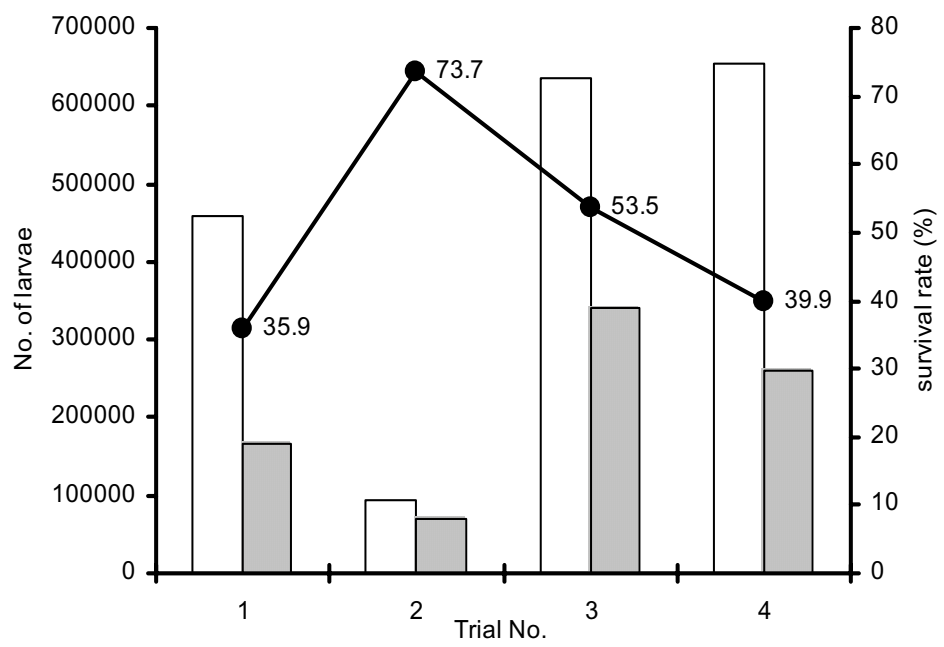

Figure 5. The number of $H$. mariae veliger larvae and their survival rates from larval development to larval presettlement. 


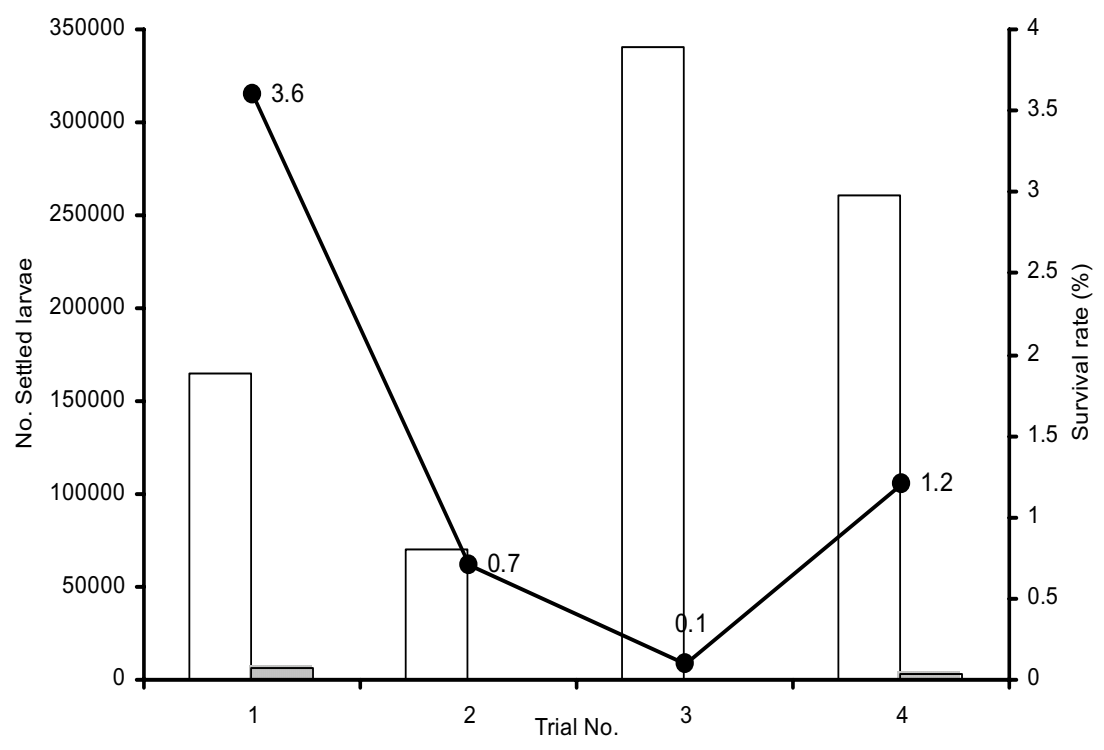

$\square$ No. introduced larvae for settlement $\square$ No. settled larvae after one month $\rightarrow$ Survival rate (\%)

Figure 6. The numbers of $H$. mariae larvae settled, and their survival rates in each trial after one month from larval pre-settlement to larval post-settlement.

larvae obtained from the four spawning trials and introduced to the settlement plates were low and varied between $35.9 \%$ and $73.7 \%$ (Fig. 5). However, 90\% has been recorded in several abalone species (Hahn, 1989). It is presumed that the mortalities are due to suboptimal water management, handling methods and temperature fluctuations (Hahn, 1989). At $25^{\circ} \mathrm{C}$ to $27^{\circ} \mathrm{C}$, the trochophore larvae metamorphosed after $56 \mathrm{~h}$ and settled after $72 \mathrm{~h}$ from hatching (Fig. 4).

The survival of settled larvae is affected by the ingestibility and digestibility of the diatom which, in turn, depends on the species dominated in the biofilm (Roberts et al., 1999). Survival rates during the postsettlement period were generally low and variable (Searcy-Bernal et al., 1992). However, the survival of the settled larvae recorded in all our four trials ranged from 0.1-3.6\% after one month (Fig. 6). These low survival rates are generally a major problem in abalone seed production (Ebert and Houk, 1984; Hahn, 1989), and were attributed to the inability to maintain the quality of diatoms (Nitzschia, Navicula, and Cocconeis) species on culture plates for abalone settlement and subsequent feeding (Mcshane, 1992; Daume et al., 2004). Growth of filamentous green algae and encrusted coralline algae on the culture plates and tank sides reduced diatom growth and quality in terms of space competition. Similar observations have been reported in tropical species such as H. varia in India (Najmudeen and Victor, 2004), perhaps as a result of high light intensity (Daume et al., 2004), which is also characteristic of Oman.

Growth of juvenile abalone was enhanced at elevated temperatures, and had reached an average length of $2.5 \mathrm{~mm} \cdot \mathrm{mo}^{-1}$ at $26^{\circ} \mathrm{C}$, in which its first respiratory pore was fully formed and visible to the naked eye (Fig. 4). Similarly, the first respiratory pore was visible after 27 days in $H$. varia at $27^{\circ} \mathrm{C}$ (Najmudeen and Victor, 2004) and 28 days in $H$. assinina at $27^{\circ} \mathrm{C}$ (Singhagraiwan and Sasaki. 1991), but after 8 weeks in $H$. rufescens at $15^{\circ} \mathrm{C}$ (Ebert and Houk, 1984) and after 43 days in H. midae (Genade et al., 1988).

Anesthetized juveniles dropped off the culture plates after an exposure time of $10-14 \mathrm{~min}$ to $1 \%$ ethanol $(12.5 \pm 1.3 \mathrm{~min}, \mathrm{n}=10)$ but this drop-off period shortened significantly to $2-4 \mathrm{~min}$ at a $2 \%$ dilution $(3.2 \pm 0.9 \mathrm{~min})$ and to $0.3-0.8 \mathrm{~min}$ at a $4 \%$ dilution $(0.55 \pm 0.15 \mathrm{~min}$; ANOVA F2,27= 476.7, 


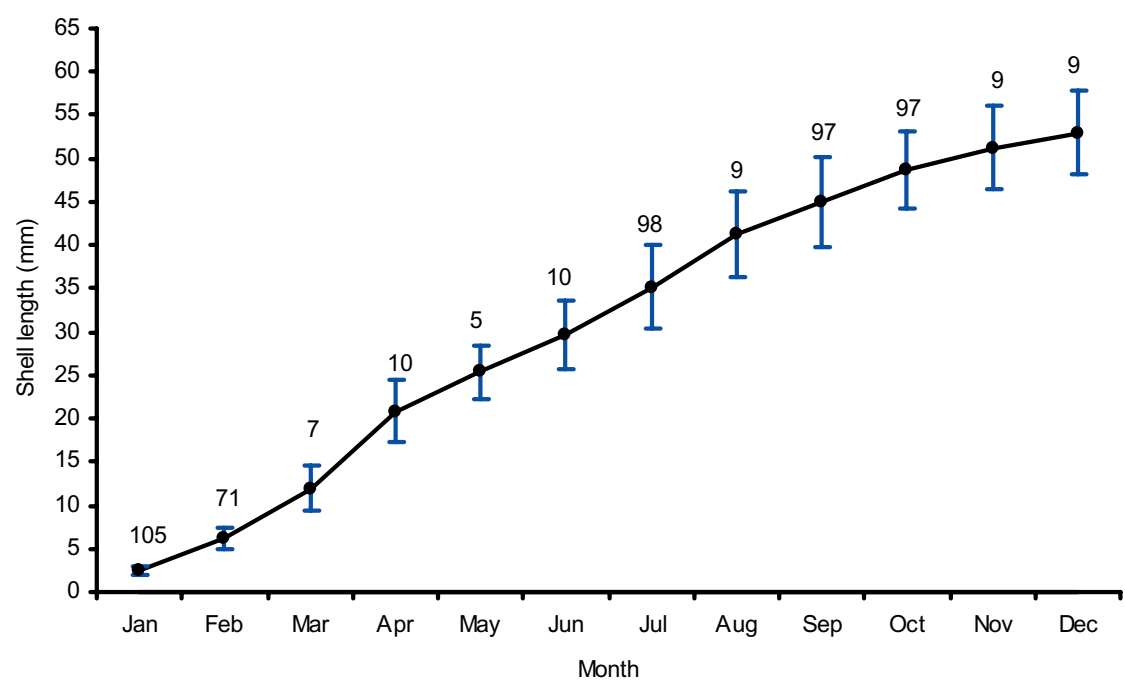

Figure 7. The average monthly the shell length ( \pm S.D.) of cultured Omani abalone, H. mariae produced at MASPS in 1999-2000. Sample size is shown above each measurement.

$\mathrm{p}<0.001)$. Recovery times were $14.7 \pm 1.9 \mathrm{~min}$ (at $1 \%), 10.4 \pm 2.4 \mathrm{~min}$ (at $2 \%$ ) and $9.0 \pm 2.2 \mathrm{~min}$ (at 4\%) (ANOVA F2, 27=35.5, p < 0.001). The later result is contrary to the expectation that recovery should take longer at higher concentrations of ethanol (Hahn, 1989). Nevertheless, the juveniles anesthetized with $4 \%$ ethanol did not resume feeding for three days, whereas feeding of the $2 \%$ group was apparently normal from the first recovery day. The drop-off and recovery times using $2 \%$ ethyl alcohol was similar to that found by Hahn (1989), using ethyl carbonic acid, magnesium sulfate and chloral hydrate on juvenile abalone.

After 13 months of rearing, juveniles reached an average size of $52.9 \mathrm{~mm}$ shell length (range 42-64.4 mm; Fig. 7). These translate to an average growth of $4.1 \mathrm{~mm} \cdot \mathrm{mo}^{-1}$. Stirn and Al-Hashmi (1996) reared abalone $(<35 \mathrm{~mm})$ collected from the wild in aquaria under closed water system and different diet regimens for 6 months, and obtained average growth of $4.8 \mathrm{~mm} \cdot \mathrm{mo}^{-1}$ with artificial diet, $3.3 \mathrm{~mm} \cdot \mathrm{mo}^{-1}$ with kelp. Ogawa (1997) grew juveniles up to $1.5 \mathrm{~mm} . \mathrm{mo}^{-}$ ${ }^{1}$ over 2 months of hatchery production. Al-Rashdi (2002) carried out a 1-month feeding experiment at MASPS using $28 \mathrm{~mm}$ juveniles fed with different diets, and obtained a growth rate of $6.39 \mathrm{~mm} \cdot \mathrm{mo}^{-1}$ with a formulated diet, $4.17 \mathrm{~mm} \cdot \mathrm{mo}^{-1}$ with frozen $U$. fasciata, and $1.17 \mathrm{~mm} \cdot \mathrm{mo}^{-1}$ with frozen brown alga $N$. zanardinii. These studies indicate that cultured $H$. mariae can grow fast on formulated diets, and also when fed fresh and frozen U. fasciata.

\section{Conclusion}

Artificial hatching and seed production of $H$. mariae have been achieved in Oman, but several challenges remain, such as locating wild abalone that are ripe enough to be spawned, improving broodstock conditioning protocols, and improving spawning success particularly for females. The low survival and settlement rates during larval development are the most important impediments to large-scale commercial aquaculture, nevertheless, the preliminary research trials described in this paper confirms that $H$. mariae can be cultured successfully in Oman. Further studies on the standardization of the culture techniques would help in stock enhancement programmes and commercial farming.

\section{Acknowledgements}

The authors would like to express their sincere thanks to Joji Ogawa who developed the research proposal of the MASPS, and to Mohamed Bal-Khair and Ali Al-Mishaikhi for technical participation in MASPS activities. Thanks are also due to Johan Groeneveld, Armando Fermin and Fahad Al-Ajmi for reading the manuscript, and to Saud Al-Habsi for his encouragement. This study was financed by the 
Oman Agricultural and Fisheries Development Fund, Sultanate of Oman.

\section{References}

Al-Hafidh, A.S. 2006. Assessment and Management of Abalone Haliotis mariae, (1828 Wood Fishery in the Omani Water. PhD. Thesis. University of Hull. Hull International Fisheries Institute. U.K.

Al-Rashdi, K.M. 2001. Preliminary Results of Abalone, Haliotis mariae, Seed Production Research Trails in Sultanate of Oman. Project Final Report. Ministry of Fisheries Wealth, Aquaculture Center, Oman.

Al-Rashdi, K.M. 2002. A Preliminary Trial on Growth and Feeding Study on Omani Juvenile Abalone, Haliotis mariae. Agricultural and Fisheries Research Bulletin. Ministry of Agriculture and Fisheries, Oman, 2:5-7.

Anon. 1984. Report of Abalone and Lobster Study in the Dhofar Region. Prepared in accordance with agreement between Waleed Associates and the Ministry of Agriculture and Fisheries. Development Application Corporation, Los Altos, California.

Ault, J. 1985. Some quantitative aspects of reproduction and growth of the red abalone, Haliotis rufescens Swainson. Journal of World Mariculture Society, 16:398 pp.

Barratt, L., R.F.G. Ormond, A. Campbell, S. Hiscock, P. Hogarth, and J. Taylor. 1984. Ecological Study of Rocky Shores on the South Coast of Oman. Report of the International Union for the Conservation of Nature and Natural Resources to the United Nations Environmental Programme, Geneva.

Barratt L., R.F.G. Ormond, and T.J. Wrathal. 1986. Ecological Studies of Southern Oman Kelp communities. Part 1. Tropical Marine Research Unit, Biology Department, University of York, UK.

Bosch, D. and E. Bosch. 1982. Seashells of Oman. Longman. London.

Capinpin, E.C. and M. Hosoya. 1995. Spawning and larval development of a tropical abalone Haliotis asinina (L.). Philippine Journal of Science, 124(3): 215-232.

Chen, H.C. 1989. Farming the small abalone, Haliotis diversicolor supertexta in Taiwan. In: Hand Book of Culture of Abalone and Other Marine Gastropods,
K.O. Hahn (Editor), 265-283. CRC Press, Boca Raton, Florida.USA.

Daume, S., S. Ryan, S.M.H. Huchette and R.W. Day. 2004. Nursery culture of Haliotis rubra: the effect of cultured algae and larval density on settlement and juvenile production. Aquaculture, 236:221239.

Daume, S. 2007. Improvement and Evaluation of Greenlip Abalone Hatchery and Nursery Production. Final FRDC Report - Project 2003/ 203. Fisheries Research Contract Report No.16, Department of Fisheries, Western Australia. $160 p p$.

Ebert, E.E. and J.L. Houk. 1984. Elements and innovations in the cultivation of red abalone Haliotis rufescens. Aquaculture, 39:375-392.

Endo, R. 2005. Abalone, Haliotis mariae, Seed Production Research Project. Project Final Report. Ministry of Fisheries Wealth. Aquaculture Center. Oman. 75pp.

Fermin, A.C., R. SJ. Gapasin, and M.N. BautistaTeruel. 2000. Spontaneous group spawning, potential and instantaneous fecundity and spawning periodicity in the donkey's ear abalone, Haliotis asinina (Linnaeus 1758). In: Proceedings of the $10^{\text {th }}$ Tropical Marine Mollusc Programme Congress and Workshop, J. Hylleberg, (Editors), 195-202. Hanoi, Vietnam,.

Freeman, K. 2001. Aquaculture and Related Biological Attributes of Abalone Species in Australia - A Review. Fisheries Research Report No.128, Department of Fisheries, Western Australia. 48pp.

Genade, A.B., A.L. Hirst, and C.J. Smith. 1988. Observations on the spawning, development and rearing of the South African abalone Haliotis midae Linn. South African Journal of Marine Science, 6:3-12.

Gordon, H.R. and P.A. Cook. 2001. World abalone supply, markets and pricing: historical, current and future. Journal of Shellfish Research, 20:567-570.

Grove-Jones, R. 1996. Hatchery reduction. In: Proceedings of the Abalone Aquaculture Workshop, A. Forster, (Editor), 14-16. Albany, Western Australia.

Grubert, M.A. and A.J. Ritar. 2005. The effect of temperature and conditioning interval on the spawning success of wild-caught blacklip (Haliotis rubra, Leach 1814) and greenlip (H. laevigata, 
Donovan 1808) abalone. Aquaculture Research, 36:654-665.

Hahn, K.O. 1989. Handbook of Culture of Abalone and Other Marine Gastropods. CRC Press, Florida, U.S.A.

Iwao, T. 2000. Abalone, Haliotis mariae, Research and Pilot Seed Production Project in Sultanate of Oman. Project Final Report. Ministry of Fisheries Wealth, Aquaculture Center, Oman. 35pp.

Johnson, D.W., A. Al-Harrasy, and M. Al-Harthy, 1992. The Sultanate of Oman Abalone Fishery. In: Abalone of the World: Biology, Fisheries and culture, S.A., Shepherd, M.J. Tegner and S.A. Guzman del Proo (Editors), 448-453. Fishing News Books, Oxford.

Jupp, B.P. 2002. Guidebook to the Seaweeds of the Sultanate of Oman. Ministry of Agriculture \& Fisheries, Marine Science \& Fisheries Center. Oman. 152pp.

Kafuku, T. and H. Ikenoue. 1983. Abalone (Haliotis discus) Culture. In: Modern Methods of Aquaculture in Japan, Developments in Aquaculture and Fisheries Science, Kafuku, T. and H. Ikenoue (Editors) 172-180. Tokyo. Japan.

Kikuchi, S. and N. Uki. 1975. Technical Study on Artificial Spawning of Abalone, Genus Haliotis. VI. On Sexual Maturation of Haliotis gigantea Gmelin Under Artificial Conditions. Bulletin of Tohoku Regional of Fisheries Research Laboratory, 35:85pp.

McShane, P.E.1992. Early Life History of Abalone: A Review. In: Abalone of the World: Biology, Fisheries and Culture, S.A., Shepherd, M.J. Tegner and S.A. Guzman del Proo (Editors), 121-131. Fishing News Books, Oxford.

Morse, D.E. 1984. Biochemical and genetic engineering for improved production of abalones and other valuable mollusks. Aquaculture, 39: 363-282.

Najmudeen, T.M. and A.C.C. Victor. 2004. Seed production and juvenile rearing of the tropical abalone Haliotis varia L. Aquaculture, 234:277292.

Ogawa, J. 1994. Feasibility Study on Stock Enhancement and Culture of Omani Abalone,
Haliotis mariae. Final Report. Ministry of Fisheries Wealth, Aquaculture Center, Oman. 16pp.

Ogawa, J. 1997. Abalone, Haliotis mariae, Seed Production in Sultanate of Oman. Final Report. Ministry of Fisheries Wealth, Aquaculture Center, Oman. 35pp.

Roberts, R.D., T. Kawamura, C.M. Nicholson. 1999. Growth and survival of postlarval abalone (Haliotis iris) in relation to development and diatom diet. Journal of Shellfish Research, 18:243-250.

Searcy-Bernal, R., A.E. Salas-Garza, A. FloresAguilar. 1992. Research in Mexico on the Critical Stage of Abalone (Haliotis spp.) Seed Production. In: Abalone of the World: Biology, Fisheries and Culture, S.A., Shepherd, M.J. Tegner and S.A. Guzman del Proo (Editors), 547-560. Fishing News Books, Oxford.

Seki, T. and H. Kan-no. 1977. Synchronized Control of Early Life in the Abalone. Haliotis discus hannai Ino, Haliotidae, Gastropoda. Bulletin of Tohoku Regional of Fisheries Research Laboratory, 38: $143 \mathrm{pp}$.

Shepherd, S.A., J.L. Baker, and D.W. Johnson. 1995. Yield per recruit and egg per recruit analyses of the Omani abalone Haliotis mariae. Marine Freshwater Research, 46:663-668.

Singhagraiwan, T. and M. Sasaki. 1991. Breeding and Early Development of the Donkey's Ear Abalone, Haliotis asinina Linne. Thailand Marine Fisheries Research Bulletin, 2:95-100.

Stirn, J. and K.A. Al-Hashmi. 1996. Contribution to the knowledge of the biology of the Arabian abalone Haliotis mariae Wood, 1828. Journal of Scientific Research-Agricultural and Marine Sciences, Sultan Qaboos University, Oman 1:33-40.

Uki, N. and S. Kikuchi. 1984. Regulation of maturation and spawning of an abalone, Haliotis (Gastropoda) by external environmental factors. Aquaculture, 39:247-261.

Yoo, S.K. 1989. Abalone Farming in Korea. In: Hand Book of Culture of Abalone and Other Marine Gastropods, K.O. Hahn (Editor), 255-263. CRC Press, Boca Raton, Florida.

Zar, J.H. 1996. Biostatistical Analysis. Prentice Hall, New Jersey, U.S.A. 